\title{
PENGARUH KEGIATAN INTRAKURIKULER DAN EKSTRAKURIKULER TERHADAP PEMBENTUKAN KARAKTER SISWA SEKOLAH MENENGAH ATAS NEGERI (SMAN) 09 BANDAR LAMPUNG
}

\author{
IMPACTS OF INTRACURRICULAR AND \\ EXTRACURRICULAR ACTIVITIES TOWARDS THE \\ FORMATION OF HIGH SCHOOL STUDENTS' \\ CHARACTERS
}

Lisa'diyah Ma'rifataini

Puslitbang Pendidikan Agama dan Keagamaan

Badan litbang dan Diklat Kementerian Agama

Jl. MH. Thamrin No.6 Jakarta Pusat

Email : lisa.litbang@gmail.com

Naskah diterima 3 April 2016, direvisi 20 Mei 2016, disetujui 10 Juli 2016

\begin{abstract}
This research is aimed at acknowledging the impacts and contributions of Islam Religion Education-based intracurricular and extracurricular activities towards the formation of characters in Public Senior High School (SMAN) 09, Bandar Lampung. This research uses quantitative method. The Research results show that the intracurricular and extracurricular activities in this school bring positive impacts towards the students' characters. For intracurricular activities, any addition of one unit activity shall result in 0.871 increase in the students' characters. Whereas for extracurricular activity, any addition of one unit activity shall result in 0.949 increase in the students' characters. The contribution of Islam religion-based intracurricular and extracurricular activities towards the students' characters is $38.8 \%$, whereas the rest is affected by other factors.
\end{abstract}

Keywords: intracurricular, extracurricular, students' characters

\section{Abstrak}

Penelitian ini bertujuan untuk mengetahui pengaruh dan kontribusi kegiatan intrakurikuler dan ekstrakurikuler berbasis Pendidikan Agama Islam terhadap pembentukan karakter di Sekolah Menengah Atas Negeri (SMAN) 09 Bandar Lampung. Penelitian ini menggunakan metode kuantitatif. Hasil penelitian menunjukkan bahwa kegiatan intrakurikuler dan ekstrakurikuler di sekolah ini berpengaruh positif terhadap karakter siswa. Untuk kegiatan intrakurikuler, setiap penambahan sebesar satu satuan akan menyebabkan meningkatnya karakter siswa sebesar 0,871. Sedang untuk kegiatan ekstrakurikuler, setiap penambahan sebesar satu satuan akan menyebabkan meningkatnya karakter siswa sebesar 0,949. Adapun kontribusi kegiatan intrakulikuler dan ekstrakulikuler berbasis pendidikan agama Islam terhadap karakter siswa sebesar $38,8 \%$, sedangkan sisanya dipengaruhi oleh faktor lain.

Kata kunci: intrakurikuler, ekstrakurikuler, karakter siswa 


\section{PENDAHULUAN}

Masalah bangsa Indonesia di berbagai bidang selama ini tidak lepas dari karakter dan nilai-nilai masyarakat. Kalau saat ini banyak kritik yang terkait dengan karakter bangsa, maka sekolah sebagai salah satu lembaga pendidikan, ikut bertanggungjawab untuk mengatasi permasalahan tersebut. Di kalangan pelajar masih dijumpai sejumlah fenomena yang menunjukkan adanya karakter yang tidak diinginkan, misalnya adanya tawuran, aksi pornografi dan porno aksi, kebiasaan mencontek, meminumminuman keras, dan tindakan kriminal lainnya yang meresahkan masyarakat.

Pasal 3, UU No 20 Tahun 2003 tentang Sistem Pendidikan Nasional menyebutkan bahwa "Pendidikan nasional berfungsi mengembangkan kemampuan dan membentuk karakter serta peradaban bangsa yang bermartabat dalam rangka mencerdaskan kehidupan bangsa". Pendidikan merupakan salah satu proses dalam membentuk, mengarahkan dan mengembangkan kepribadian serta kemampuan seseorang.

Untuk mendukung terlaksananya pendidikan karakater di sekolah telah disiapkan sejumlah peraturan mulai dari Peraturan Presiden, Peraturan Menteri, sampai Peraturan di bawahnya. Diantaranya telah dibuat Kebijakan Nasional Pembangunan Budaya dan Karakter Bangsa, Desain Induk Pendidikan Karakter Kementerian Pendidikan Nasional, Panduan Pelaksanaan Pendidikan Karakter, dan beberapa pedoman pelaksanaan pendidikan karakter di berbagai jenjang pendidikan.

Berkenaan dengan itu, sekitar tahun 2010 yang lalu, mulai dicanangkan
Pendidikan Karakater untuk dilaksanakan di sekolah secara bertahap, mulai dari Sekolah Dasar, Sekolah Menengah Pertama, Sekolah Menengah Atas, dan Sekolah Menengah Kejuruan. Bahkan mulai tahun ajaran 2013/2014, sekolah mulai menerapkan kurikulum 2013 dimana kurikulum tersebut berbasis karakter.

Pendidikan merupakan salah satu proses dalam membentuk, mengarahkan dan mengembangkan kepribadian serta kemampuan seseorang. Pembinaan kepribadian/karakter atau jiwa utuh hanya mungkin dibentuk melalui pengaruh lingkungan, khususnya pendidikan. Sasaran yang dituju dalam pembentukan kepribadian/karakter ini adalah terciptanya pribadi yang memiliki akhlak yang mulia yang sangat erat kaitannya dengan tingkat keimanan.

Pendidikan agama Islam diharapkan menghasilkan manusia yang selalu berupaya menyempurnakan iman, takwa, akhlak, serta aktif membangun peradaban dan keharmonisan kehidupan, khususnya dalam memajukan peradaban bangsa yang bermartabat. Pendidikan agama Islam di sekolah dimaksudkan untuk meningkatkan potensi moral dan spiritual yang mencakup pengenalan, pemahaman, penanaman, dan pengamalan nilai-nilai keagamaan dalam kehidupan individual ataupun kolektif kemasyarakatan. Pendidikan agama Islam di sekolah bertujuan untuk menumbuhkan dan meningkatkan keimanan melalui pemberian dan pemupukan pengetahuan, penghayatan, pengamalan, serta pengalaman peserta didik tentang agama islam sehingga menjadi manusia muslim yang terus berkembang dalam hal keimanan, ketakwaannya, berbangsa dan bernegara. 
Di tengah kegelisahan yang menghinggapi berbagai komponen bangsa tersebut, terdapat beberapa lembaga pendidikan atau sekolah yang telah melaksanakan pendidikan karakter secara berhasil dengan model yang mereka kembangkan sendiri sehingga sekolah tersebut dinamakan best practice. Banyak model penyelenggaraan pendidikan karakter yang telah dilaksanakan di sekolahsekolah tersebut, baik yang dilakukan melalui kegiatan intrakurikuler maupun ekstrakurikuler. Berdasarkan hal inilah penelitian ini ingin mengetahui bagaimana kontribusi kegiatan tersebut terhadap pembentukan karakter siswa.

Apakah terdapat pengaruh positif kegiatan intrakurikuler berbasis Pendidikan Agama Islam terhadap karakter siswa? Apakah terdapat pengaruh positif kegiatan ekstrakurikuler berbasis Pendidikan Agama Islam terhadap karakater siswa, dan bagaimana kontribusi kegiatan intrakurikuler dan ekstrakurikuler berbasis Pendidikan Agama Islam terhadap pembentukan karakater siswa? Pertanyaanpertanyaan inilah yang hendak dijawab dalam penelitian ini.

\section{Kerangka Teori}

\section{Pengaruh Pendidikan Agama terhadap Pembentukan Karakter Siswa}

Peraturan Pemerintah Nomor 55 Tahun 2007 tentang Pendidikan Agama dan Pendidikan Keagamaan menyebutkan bahwa pendidikan agama adalah pendidikan yang memberikan pengetahuan dan membentuk sikap, kepribadian dan keterampilan peserta didik dalam mengamalkan ajaran agamanya, yang dilaksanakan sekurang kurangnya melalui mata pelajaran/kuliah pada semua jalur, jenjang, dan jenis pendidikan. ${ }^{1}$

Hubungan antara pendidikan karakter dengan Pendidikan Agama Islam misalnya dapat dilihat dalam dua sisi, yakni materi dan proses pembelajaran. Dari segi materi, Pendidikan Agama Islam mencakup nilai pendididikan karakter. Hal ini bisa dilihat dalam tabel berikut ini:

Tabel 1 :

Contoh Nilai Pendidikan Karakter dalam Pendidikan Agama Islam

\begin{tabular}{|l|l|}
\hline \multicolumn{1}{|c|}{ Aspek } & \multicolumn{1}{c|}{ Nilai Karakter } \\
\hline $\begin{array}{l}\text { al-Qur'an (ayat-ayat al-Qur'an } \\
\text { tentang manusia dan tugas } \\
\text { sebagai khalifah di muka bumi, } \\
\text { keikhlasan dalam beribadah, } \\
\text { demokrasi, kompetisi dalam } \\
\text { kebaikan, perintah menyantuni } \\
\text { kaum dhu'afa, perintah menjaga } \\
\text { lingkungan hidup, dan lain-lain). }\end{array}$ & $\begin{array}{l}\text { Religius, jujur, toleransi, disiplin, } \\
\text { kerja keras, kreatif, mandiri, } \\
\text { peduli sosial dan tanggungjawab. }\end{array}$ \\
\hline $\begin{array}{l}\text { Akidah (iman kepada Allah } \\
\text { melalui pemahaman sifat- } \\
\text { sifatNya). }\end{array}$ & $\begin{array}{l}\text { Religius, jujur, toleransi, disiplin, } \\
\text { kerja keras, kreatif, mandiri, } \\
\text { peduli sosial dan tanggungjawab. }\end{array}$ \\
\hline $\begin{array}{l}\text { Akhlak (perilaku terpuji, } \\
\text { menghindari perilaku tercela). }\end{array}$ & $\begin{array}{l}\text { Religius, jujur, toleransi, disiplin, } \\
\text { kerja keras, kreatif, mandiri, } \\
\text { demokratis, rasa ingin tahu, } \\
\text { semangat kebangsaan, cinta } \\
\text { tanah air, menghargai prestasi, } \\
\text { bersahabat/ komunikatif, cinta } \\
\text { damai, gemar membaca, peduli } \\
\text { lingkungan, peduli sosial, } \\
\text { tanggung jawab. }\end{array}$ \\
\hline
\end{tabular}

Sedangkan dalam proses pembelajaran, guru dalam mengajar Pendidikan Agama Islam ke peserta didik harus memasukkan muatan pendidikan karakter. Perencanaan Pendidikan Karakter dalam PAI dilakukan sejak saat penyusunan silabus dan rencana pelaksanaan pembelajaran (RPP).

Berdasarkan penulusuran dokumen silabus dan RPP, pendidikan karakter dalam

1 Peraturan Pemerintah No. 55 Tahun 2007 Tentang Pendidikan Agama dan Pendidikan Keagaman Pasal 1 ayat 1 . 
PAI memasukkan nilai -nilai pendidikan karakter dengan melihat standar kompetensi (SK). SK PAI yang diajarkan memasukkan nilai -nilai pendidikan karakter religius memahami ayat-ayat al-Qur'an tentang manusia dan tugasnya sebagai khalifah di bumi, menampilkan sikap berprasangka baik (husnuzhan) terhadap Allah, rajin beribadah, berdo'a secara khusuk, meningkatkan keimanan kepada Malaikat, membiasakan perilaku terpuji, memahami ayat-ayat al-Qur'an tentang kompetisi dalam kebaikan, memahami ayat-ayat alQur'an tentang perintah menyantuni kaum dhu'afa, meningkatkan keimanan kepada rasul-rasul Allah, membiasakan berperilaku terpuji, memahami hukum Islam tentang mu'amalah, memahami perkembangan Islam pada abad pertengahan (1250-1800), meningkatkan keimanan kepada kitabkitab Allah, menghindari perilaku tercela (dosa-dosa besar), memahami ketentuan hukum Islam tentang pengurusan jenazah, memahami khutbah, tabligh dan dakwah, meningkatkan keimanan kepada hari akhir, memahami sifat adil, ridha, dan amal saleh, memahami ayat-ayat al-Quran tentang pengembangan ilmu pengetahuan dan teknologi, dan meningkatkan keimanan kepada Qadha dan Qadar.

Sedangkan nilai karakter kejujuran dimasukkan dalam standar kompetensi menghindari prilaku tercela, meningkatkan keimanan kepada rasul-rasul Allah, membiasakan berperilaku terpuji, memahami perkembangan Islam pada abad pertengahan (1250-1800), menghargai karya orang lain, meningkatkan keimanan kepada hari akhir, meningkatkan keimanan kepada qadha dan qadar, dan memahami hukum Islam tentang waris.
Nilai toleransi dimasukkan dalam Standar Kompetensi memahami ayat-ayat alQuran tentang demokrasi, meningkatkan keimanan kepada Kitab-kitab Allah, memahami ketentuan hukum Islam tentang pengurusan jenazah, memahami khutbah, tabligh dan dakwah, memahami ayat-ayat al-Quran tentang anjuran bertoleransi, memahami perkembangan Islam di dunia. Misalnya indikator pelaksanaan nilai karakter didalam kelas adalah pelaksanaan Pendidikan Karakter di dalam kelas adalah berdoa sebelum dan sesudah pelajaran dan memberikan kesempatan kepada semua peserta didik untuk melaksanakan ibadah. Sedangkan indikator pelaksanaan Pendidikan Karakter kejujuran di dalam kelas diantaranya menyediakan fasilitas tempat, temuan barang hilang, tempat pengumuman barang temuan atau hilang, tranparansi laporan keuangan, dan penilaian kelas secara berkala, larangan menyontek.

Nilai karakter disiplin dimasukkan dalam standar kompetensi meningkatkan keimanan kepada malaikat, membiasakan perilaku terpuji, menghindari perilaku tercela (dosa besar), meningkatkan keimanan kepada rasul-rasul Allah, membiasakan berperilaku terpuji (mencerminkan perilaku taubat dan raja'), memahami khutbah, tabligh dan dakwah, memahami ayat-ayat al-Quran tentang etos kerja. Karakter disiplin dapat diterapkan dengan membiasakan hadir tepat waktu ke sekolah, membiasakan mematuhi aturan, dan menggunakan pakaian sekolah sesuai dengan aturan.

Dari penjelasan di atas kelihatan sangat jelas bahwa pendidikan agama sangat berpengaruh dalam pembentukan karakter siswa. Namun demikian, banyak juga faktor 
lain yang dapat mempengaruhi karakter siswa dalam proses pembelajaran.

\section{Kajian Terdahulu}

Berbagai model penyelenggaraan pendidikan karakter telah dilaksanakan di sekolah-sekolah, baik yang dilakukan melalui intrakurikuler maupun ekstrakurikuler. Suprapto, Puslitbang Pendidikan Agama dan Keagamaan, dalam penelitiannya tentang pendidikan karakter melalui Pendidikan Agama Islam (PAI) di Sekolah Menengah Atas Negeri (SMAN) 23 Bandung menyatakan bahwa pendidikan karakter bisa diselenggarakan melalui kegiatan intrakurikuler dan ekstrakurikuler. Pada konteks ini, peran guru menjadi sangat penting dimana ia mempunyai peran: 1) merencanakan pembelajaran PAI secara eksplisit memasukkan nilai-nilai karakter yang relevan dengan isi pelajaran, 2) melakukan deskripsi, ekplanasi, dan elaborasi, 3) melakukan pengamatan perilaku dan karakter peserta didik sepanjang proses pembelajaran, 4) terlibat secara aktif dalam menanamkan karakter melalui praktek pengamalan agama di luar kelas, 5) bersama Kepala Sekolah, Tenaga Umum (TU), dan Pengawas menciptakan budaya sekolah yang berkarakter.

Berikutnya penelitian Lisa'diyah pada tahun 2014 di SMA Negeri 09 Bandar Lampung. Penelitian ini menyatakan sebuah kesimpulan bahwa melalui kegiatan intrakurikuler guru harus menguasai bahan pelajarannya dan harus mampu memotifasi peserta didiknya agar menyenangi pelajaran tersebut. Pembelajaran pendidikan karakter dilakukan dengan menyisipkan beberapa kegiatan hidden curricullum berupa pengintegrasian dengan semua mata pelajaran. Berkaitan dengan kegiatan pembelajaran, guru dapat memasukkan nilai-nilai karakter pada content materinya, metode, dan evaluasinya.

Model penanaman nilai-nilai karakter siswa pada kegiatan ekstrakurikuler dilakukan dengan menginternalisasikan nilai-nilai karakter pada siswa, sebelum mata pelajaran dimulai dengan membaca ayat pendek/membaca kitab/berdo'a selama 15 menit. Penanaman nilai-nilai karakter juga dilakukan dengan menciptakan lingkungan yang kondusif dan agamis, melakukan pemasangan slogan-slogan yang berisi tulisan pesan-pesan moral di setiap tempat yang strategis, membuat kegiatan kerokhanian, membuat aturan-aturan, dan melalui perayaan hari-hari besar agama.

Kajian penelitianterdahulu sebagaimana diuraikan di atas terlihat hanya meneliti sebatas model-model penyelenggaraan kegiatan intrakurikuler dan ekstrakurikuler. Sebagai tidak lanjut dari hasil penelitian tersebut maka penting untuk mencari hubungan antara keduanya. Dengan kata lain, pengaruh dan kontribusi dari model pendidikan karakter berbasis pendidikan agama tersebut terhadap karakter siswa menjadi kajian penting untuk melengkapi kedua penelitian di atas.

\section{METODE PENELITIAN}

Penelitian ini merupakan penelitian studi kasus dengan pendekatan metode kuantitatif. Sasaran penelitian adalah SMA Negeri 09 Bandar Lampung, sebuah SMA yang telah menyelenggarakan Kurikulum 2013. Sumber data diperoleh melalui informan yaitu Kepala Sekolah, guru 
Pendidikan Agama Islam dan siswa. Teknik pengumpulan data dilakukan melalui angket, wawancara mendalam, dokumentasi, dan observasi.

Analisis data dilakukan menggunakan metode statistika, yaitu dengan analisis deskriptifmelalui penyajian data secara rinci, rangkuman statistik, dan uji persyaratan analisis untuk mengantisipasi terjadinya bias data. Analisis korelasi digunakan untuk menguji apakah terdapat pengaruh antara variabel bebas dengan variabel terikat, dan apakah kegiatan intrakurikuler dan ekstrakurikuler berkorelasi positif terhadap pembentukan karaketer siswa. Analisis regresi linier berganda digunakan untuk mengukur seberapa besar kontribusi dua vareabel tersebut yaitu variable bebas (intrakurikuler/X1 dan ekstrakurikuler/X2) terhadap variabel terikat (karakter siswa/Y).

Dalam menentukan jumlah sampel, penulis mengikuti pendapat suharsimi Arikunto ${ }^{2}$ yang berpendapat bahwa: "Untuk sekedar ancer-ancer, maka apabila subjeknya kurang dari 100, lebih baik diambil semua sehingga penelitiannya merupakan penelitian populasi. Selanjutnya jika jumlah subjeknya besar dapat diambil antara 10 $15 \%$, atau 20 - 25\% atau lebih". Berdasarkan data Profil SMA Negeri 09 Bandar Lampung pada tahun 2015 jumlah Siswa Muslim secara keseluruhan sebanyak 960 anak. Sedang jumlah siswa yang dijadikan sampel sebanyak 174 siswa. Karena jumlah sampel menunjukkan prosentasi sebesar 18,2\% melebihi dari $15 \%$ dengan demikian sampel ini sudah representatif.

${ }^{2}$ Suharsimi Arikunto. 2002. Prosedur penelitian Suatu Pendekatan Praktek, Jakarta: Rineka Cipta, h. 112.

\section{Hipotesis}

Penelitian ini menetapkan beberapa variabel yang akan diuji secara empirik kesahihannya, yaitu kegiatan intrakurikuler (X1), kegiatan ekstrakurikuler (X2) dan karakter siswa (Y).

\section{Hipotesis I}

Ho: $\beta_{1} \leq 0$, Tidak ada pengaruh positif kegiatan intrakurikuler Pendidikan Agama Islam terhadap pembentukan karakter siswa.

$\mathrm{H}_{1}: \beta_{1}>0$, Ada pengaruh positif kegiatan intra strkurikuler Pendidikan Agama Islam terhadap karakter siswa.

\section{Hipotesis II}

Ho: $\beta 2 \leq 0$, Tidak ada pengaruh positif kegiatan ektrakurikuler Pendidikan Agama Islam terhadap pembentukan karakter siswa.

H1 : $\beta 2>0$, Ada pengaruh positif kegiatan ekstrakurikuler Pendidikan Agama Islam terhadap karakter siswa.

Hipotesis III

Ho: $\beta 1=\beta 2=0$, Persamaan regresi tidak signifikan

$\mathrm{H}_{1}: \beta_{1} \neq 0, \beta 2 \neq 0, \beta 1 \beta 2 \neq 0$, Minimal satu $\beta_{\mathrm{i}} \neq 0, \mathrm{i}=1,2$, persamaan regresi signifikan, salah satu antara kegiatan ekstrakurikuler dan intrakurikuler atau secara bersamasama berpengaruh terhadap karakter siswa secara signifikan.

\section{HASIL DAN PEMBAHASAN}

Karakter seseorang bisa dipengaruhi oleh lingkungan keluarga, sekolah dan sosial budaya. ${ }^{3}$ Lingkungan sekolah dapat

${ }^{3}$ Disampaikan oleh Oki Septiana Dewi, pembicara Program itu Indah, pada acara Seminar Kontribusi 
dibedakan menjadi beberapa variabel. Namun penelitain ini dibatasi hanya mengambil 2 variabel bebas yaitu kegiatan intrakurikuler (X1) yang merupakan kegiatan pengembangan diri yang dilaksanakan sebagian besar di dalam kelas dan kegiatan ekstrakurikuler (X2) yang merupakan kegiatan tambahan di luar struktur program yang dilakasanakan di luar jam pelajaran. Sedangkan variabel terikatnya adalah karakter siswa (Y).

Sebelum dilakukan pengukuran atau penilaian dari masing-masing variabel, perlu dibuat kriteria nilai dari masing-masing variabel agar angka atau nilai variabel tersebut bisa ditafsirkan secara kualitatif. Jumlah item pernyataan dari masingmasing variabel berbeda sehingga klasifikasi nilainya berbeda meskipun pengkategorian nilainya sama. Adapun pengkategorian nilai-nilai pencapaian untuk masing-masing vareabel sebagai berikut:

Untuk variabel Kegiatan Intrakurikuler (X1), dengan jumlah pernyataan dalam instrumen sebanyak 31 item, mendapatkan nilai tertinggi 155 dan nilai terendah 31, apabila dikategorikan menjadi 5 hasilnya sebagai berikut: 131- 155 = Sangat Baik; 106 $-130=$ Baik; $81-105=$ Kurang Baik; $56-80=$ Tidak Baik dan $31-55$ = Sangat Tidak Baik

Untuk variabel Kegiatan Ekstrakurikuler (X2), dengan jumlah pernyataan sebanyak 34 item, nilai tertinggi 170, nilai terendah 34 , dikategorikan menjadi 5 , hasilnya sebagai berikut: $143-170=$ Sangat Baik, $116-142=$ Baik, $89-115=$ Kurang Baik, $62-88=$ Tidak Baik dan $34-61=$ Sangat Tidak Baik.

Media terhadap Pendidikan Agama pada tanggal 5-7 Oktober 2016.
Adapun variabel Karakter Siswa (Y), dengan jumlah pernyataan sebanyak 89 item, skor tertinggi 445, skor terendah 89, dikategorikan menjadi 5 , hasilnya sebagai berikut: $374-445=$ Sangat Baik, $303-373$ = Baik, $232-302=$ Kurang Baik, 161- $231=$ Tidak Baik dan $89-160=$ Sangat Tidak Baik.

\section{Distribusi Frekuensi Nilai Kegiatan Intrakurikuler (X1)}

Kegiatan intrakurikuler adalah kegiatan pengembangan diri siswa yang dilaksanakan sebagian besar di dalam kelas. Untuk mengetahui nilai siswa pada kegiatan intrakurikuler ini diukur dengan memberikan instrumen kepada siswa yang bersangkutan, seberapa sering melakukan atau mengikuti kegiatan tersebut. Data hasil penelitian menunjukkan bahwa 174 responden yang dijadikan sampel penelitian terdapat 97 siswa $(55,7 \%)$ mengikuti kegiatan ini sangat baik, mengikuti dengan baik 71 siswa $(40,8 \%)$, kurang baik 5 siswa $(2,9 \%)$ dan hanya 1 siswa mengikuti dengan tidak baik $(0,6 \%)$. Untuk mengetahui nilai kegiatan intrakurikuler secara jelas dapat dilihat pada tabel berikut ini :

Tabel 2:

Distribusi Frekuensi Nilai Kegiatan Intrakurikuler (X1)

\begin{tabular}{|l|c|c|}
\hline \multicolumn{1}{|c|}{ Nilai Intrakurikuler } & Frekuensi & Persen \\
\hline Sangat Baik & 97 & 55,7 \\
\hline Baik & 71 & 40,8 \\
\hline Kurang Baik & 5 & 2.9 \\
\hline Tidak Baik & 1 & 0,6 \\
\hline Total & 174 & 100 \\
\hline
\end{tabular}

Adapun untuk kegiatan intrakulikuler ini, siswa secara umum memiliki kategori kesesuaian yang sangat tinggi terhadap 
semua item pertanyaan yang mereka presentasikan pada kegiatan tersebut. Sejumlah 55,7 \% siswa SMA Negeri Bandar lampung mengikuti kegiatan intrakurikuler sangat baik.

\section{Distribusi Frekuensi Nilai Kegiatan Ekstrakurikuler (X2)}

Kegiatan ekstrakurikuler adalah kegiatan-kegiatan di luar struktur program yang dilaksanakan di luar jam pelajaran biasa yang bertujuan untuk membina karakter siswa. Untuk mengetahui nilai siswa pada kegiatan ekstrakurikuler ini diukur dengan memberikan instrumen kepada siswa yang bersangkutan, seberapa sering mereka melakukan atau mengikuti kegiatan tersebut. Data hasil penelitian menunjukkan bahwa 174 responden yang dijadikan sampel penelitian terdapat 10 siswa (5,7\%) yang mengikuti kegiatan ini sangat baik, yang tergolong baik 120 siswa (69,0\%), kurang baik 44 siswa $(25,3 \%)$ dan tidak ada siswa mengikuti dengan tidak baik. Untuk mengetahui nilai kegiatan ekstrakurikuler secara jelas dapat dilihat pada tabel berikut ini :

Tabel 3:

Distribusi Frekuensi Nilai Kegiatan Ekstrakurikuler (X2)

\begin{tabular}{|l|c|c|}
\hline \multicolumn{1}{|c|}{ Ekstra Kurikuler } & Frekuensi & Persen \\
\hline Sangat Baik & 10 & 5,7 \\
\hline Baik & 120 & 69,0 \\
\hline Kurang Baik & 44 & 25,3 \\
\hline Tidak Baik & 0 & 0 \\
\hline Total & 174 & 100 \\
\hline
\end{tabular}

Pada kegiatan ekstrakurikuler, siswa secara umum memiliki kategori kesesuaian yang tinggi terhadap semua item pertanyaan yang mereka presentasikan pada tingkat kegiatan tersebut. Sejumlah 69\% siswa SMA Negeri Bandar lampung mengikuti kegiatan ekstrakurikler dengan baik.

\section{Distribusi Frekuensi Nilai Karakter Siswa (Y)}

Karakter merupakan ciri khas yang dimiliki oleh individu. Ciri khas tersebut mengakar pada kepribadian individu yang merupakan mesin pendorong bagaimana seseorang bertindak, berujar, dan merespon sesuatu yang berkaitan dengan konsep moral (moral knowing), sikap moral (moral felling), dan prilaku moral (moral behavior).

Untuk mengetahui nilai karakter siswa ini diukur dengan memberikan instrumen kepada siswa yang bersangkutan terhadap pernyataan pada dirinya terhadap 7 karakter siswa yang berdekatan dengan Pendidikan Agama Islam. Data hasil penelitian menunjukkan bahwa 174 responden yang dijadikan sampel penelitian terdapat 58 siswa $(33,3 \%)$ yang memiliki karakter sangat baik, karakter baik 110 siswa (63,2\%), kurang baik 6 siswa $(3,4 \%)$ dan tidak terdapat siswa yang berkarakter tidak baik.

Untuk mengetahui nilai kegiatan intrakurikuler secara jelas dapat dilihat pada tabel berikut ini :

Tabel 4 :

Distribusi Frekuensi Nilai Karaker Siswa (Y)

\begin{tabular}{|l|c|c|}
\hline \multicolumn{1}{|c|}{ Karakter } & Frekuensi & Persen \\
\hline Sangat baik & 58 & 33.3 \\
\hline Baik & 110 & 63.2 \\
\hline Kurang Baik & 6 & 3.4 \\
\hline Tidak Baik & 0 & 0 \\
\hline Total & 174 & 100 \\
\hline
\end{tabular}


Mengacu pada tingkat persentase di atas, dapat disimpulkan bahwa seluruh siswa yang memberikan jawaban atas item pertanyaan yang diajukan menunjukkan tingkat karakter siswa tinggi atau mendekati tingkat yang diharapkan dalam pertanyaan tersebut.

Selain itu, apabila jawaban yang diberikan siswa dianalisa lebih jauh, dapat diketahui bahwa karakter siswa secara umum dikategorikan bahwa siswa memiliki tingkat kesesuaian yang tinggi pada semua item pertanyaan yang mempresentasikan perilaku yang mereka lakukan. Sebelum dilakukan penghitungan analisis statistik inferensial yaitu analisis regresi dan analisis korelasi serta pengujian hipotesisnya perlu dikaji terlebih dahulu statistik deskriptif dari masing-masing variabel penelitian dan melakukan uji persyaratan analisis.

\section{Deskriptif Statistik Nilai dari Masing- Masing Variabel}

Hasil pengolahan data terhadap masing masing variabel menunjukkan akumulasi rata-rata, standar deviasi dan jumlah sampel yang dijadikan obyek penelitian menunjukkan bahwa: 1) rata-rata (mean) nilai karakter siswa dengan jumlah sampel 174 siswa adalah 360.45, dengan standar deviasi 30.539, menunjukkan bahwa tingkat karakter siswa dalam kategori baik, 2) rata-rata nilai intrakulikuler dengan jumlah sampel 174 adalah 130.87, dengan standar deviasi 11.366, menunjukkan bahwa nilai kegiatan intrakulikuler di SMAN Lampung secara umum baik, 3) rata-rata nilai ekstrakulikuler dengan jumlah sampel 174 adalah 124.13, dengan standar deviasi 12.759, menunjukkan bahwa rata-rata nilai kegiatan ekstrakulikuler di SMAN Lampung termasuk kategori baik.

Untuk menilai karakter siswa, kegiatan intrakulikuler dan ekstrakulikuler, selain melihat rata-rata dari jawaban siswa berdasarkan tabel statistik deskriptif di atas juga bisa dilihat berdasarkan skor jawaban siswa yang dilakukan dengan melihat persentase total skor jawaban yang diperoleh terhadap total skor jawaban maksimal yang diharapkan. Adapun untuk menghitung total skor jawaban maksimal yang diharapkan menggunakan rumus sebagai berikur:

Total skor maks $=$ jmlh siswa $\mathrm{x}$ jmlh item pertanyaan $\mathrm{x}$ skor tertinggi ${ }^{4}$

Melalui metode perhitungan tersebut diperoleh hasil perhitungan pada tabel berikut ini:

Tabel 5 :

Hasil Persentase Total Jawaban Siswa

\begin{tabular}{|c|c|c|c|}
\hline Variabel & $\begin{array}{c}\text { Total skor yang } \\
\text { diperoleh }\end{array}$ & $\begin{array}{c}\text { Total skor } \\
\text { Maks }\end{array}$ & $\begin{array}{c}\text { Persentase } \\
\text { (\%) }\end{array}$ \\
\hline Karakter Siswa (Y) & 62719 & 77430 & 81 \\
\hline Intrakulikuler (X1) & 22771 & 26970 & 84 \\
\hline Ekstrakulikuler (X) & 21598 & 29580 & 73 \\
\hline
\end{tabular}

Tabel di atas menunjukkan nilai total skor jawaban siswa atas item pertanyaan terkait karakter siswa adalah 62719 atau 81 $\%$ dari total skor maksimal sebesar 74430, ini berarti bahwa karakter siswa yang diukur berdasarkan item pertanyaan yang diajukan dalam penelitian ini sebesar $81 \%$ dari tingkat

${ }^{4}$ Sugiyono. 2009. Metode Penelitian Kuantitatif, Kualitatif, dan $R$ \& D, Bandung: Alfabeta, Cetakan Ketujuh. h. 305. 
nilai karakter siswa yang diharapkan. Untuk total skor jawaban siswa atas item pertanyaan terkait kegiatan intrakurikuler adalah 22771 atau $84 \%$ dari total skor maksimal sebesar 26970. Ini berarti bahwa tingkat kegiatan intrakurikuler siswa yang diukur berdasarkan item pertanyaan yang diajukan dalam penelitian ini sebesar $84 \%$ dari tingkat kegiatan intrakurikuler siswa yang diharapkan.

Adapuntotalskorjawabansiswaatasitem pertanyaan tingkat kegiatan ekstrakurikuler siswa adalah 21598 atau $73 \%$ dari total skor maksimal sebesar 29580. Ini berarti bahwa tingkat kegiatan ekstrakurikuler siswa yang diukur berdasarkan item pertanyaan yang diajukan dalam penelitian ini sebesar $80 \%$ dari tingkat kegiatan ekstrakurikuler siswa yang diharapkan

Mengacu pada tingkat persentase diatas, dapat disimpulkan bahwa seluruh siswa yang memberikan jawaban atas item pertanyaan yang diajukan menunjukkan tingkat karakter siswa, kegiatan intrakurikuler dan ekstrakurikuler siswa sangat tinggi atau mendekati tingkat yang diharapkan dalam pertanyaan tersebut.

\section{Uji Persyaratan Analisis}

Sebelum dilakukan pengujian hipotesis menggunakan regresi linier berganda, ada beberapa persyaratan yang harus dipenuhi agar kesimpulan dari regresi tersebut tidak bias, yaitu dengan uji normalitas, uji multikolinieritas, uji autokorelasi, uji heteroskodesitas dan uji linieritas.

\section{Hasil Uji Normalitas}

Uji normalitas dilakukan untuk mengetahui apakah data yang diambil dalam penelitian berasal dari populasi yang berdistribusi normal atau tidak. Model regresi yang baik adalah yang datanya berdistribusi normal atau mendekati normal. Jika data tidak berada di sekitar wilayah garis diagonal dan tidak mengikuti garis diagonal atau tidak mengikuti pola sebaran distribusi normal maka akan diperoleh taksiran yang bias. Pengujian normalitas dalam penelitian ini yaitu melalui normal probability plot dengan menggunakan bantuan aplikasi computer statistic SPSS dan diperoleh hasil sebagai berikut:

$$
\text { Grafik 1. Uji Normalitas }
$$

Normal P-P Plot of Regression Standardized Residual

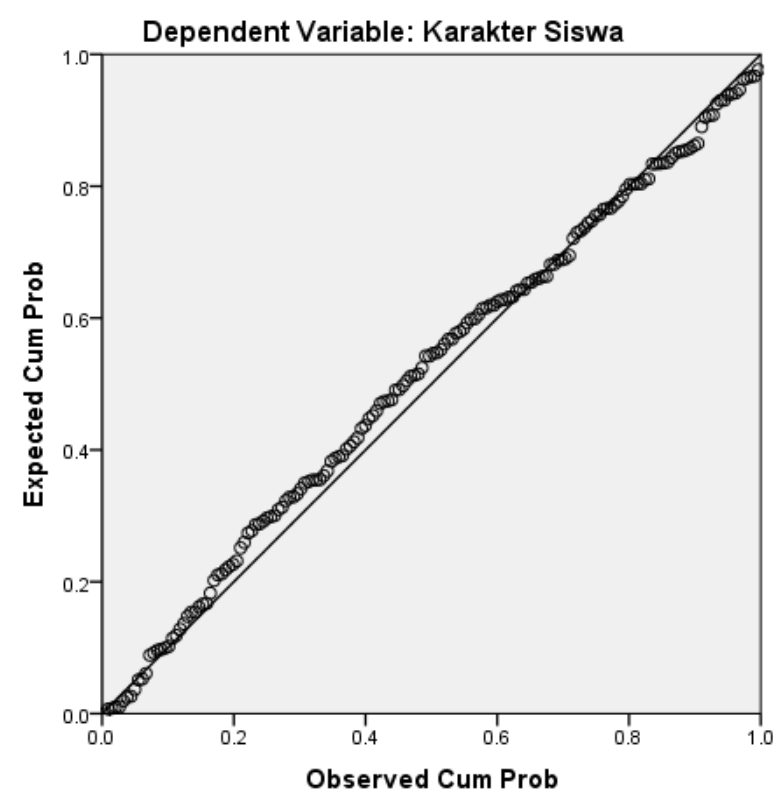

Uji normalitas dengan normal probability plot mensyaratkan bahwa penyebaran data harus berada di sekitar wilayah garis diagonal dan mengikuti arah garis diagonal. Berdasarkan gambar di atas dapat disimpulkan bahwa data dalam penelitian ini memenuhi syarat normal probability plot 
sehingga model regresi dalam penelitian memenuhi asumsi normalitas ( berdistribusi normal ). Artinya data dalam penelitian ini berasal dari populasi yang berdistribusi normal.

\section{Hasil Uji Multikolinieritas}

Uji multikolinieritas bertujuan untuk mengujiada tidaknyakorelasiantara variabel independent (bebas) dan variabel dependent (terikat) dalam suatu model regresi. Uji multikolinieritas dalam penelitian ini dilakukan dengan melihat nilai variance inflation factor ( VIF ) dengan menggunakan SPSS dan diperoleh hasil yang sesuai dengan ketentuan uji multikolinieritas. jika nilai VIF kurang dari 10 maka tidak terdapat multikolinieritas.

Berdasarkan hasil penghitungan terlihat bahwa nilai VIF yaitu 1,361 kurang dari 10 . Dengan demikian dapat disimpulkan bahwa tidak terdapat multikolinieritas dalam data penelitian ini. Artinya bahwa antara variabel bebas Intrakulikuler (X1) dan Ekstrakulikuler (X2) tidak saling mempengaruhi.

\section{Hasil Uji Heteroskodesitas}

Uji heteroskodesitas dilakukan untuk menguji apakah dalam suatu model regresi terjadi perbedaan variance dari residual data yang ada. Dalam penelitian ini uji heteroskodesitas dilakukan dengan analisa grafik plot antara nilai prediksi variabel terikat (ZPRED) dengan variabel terikat (Karakter Siswa). Pengujian ini menggunakan SPSS dengan hasil sebagai berikut:

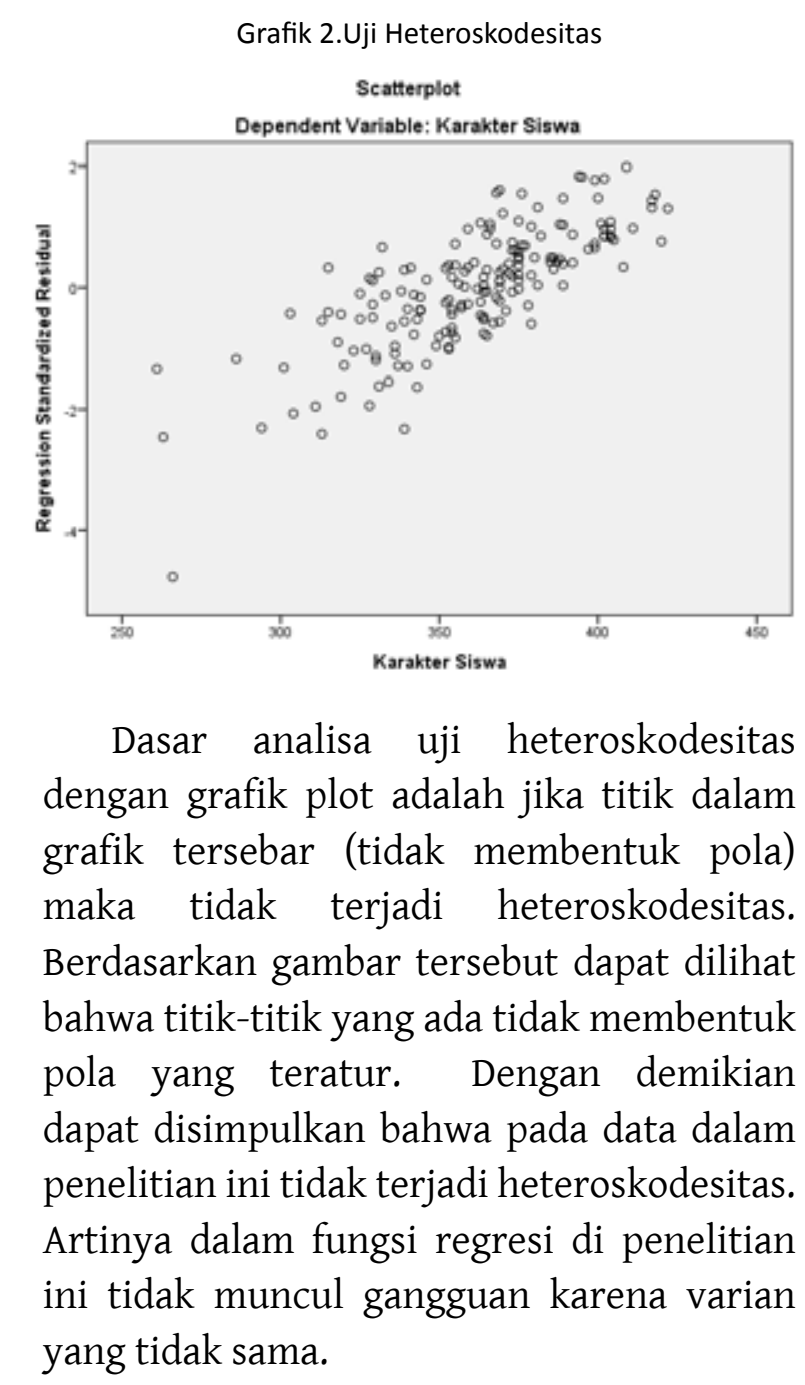

\section{Hasil Uji Linieritas}

Uji linearitas adalah pengujian yang bertujuan untuk mengetahui apakah regresi bersifat linier atau tidak. Uji linieritas dalam penelitian ini menggunakan tabel ANOVA variabel $X$ dan $Y$ dari nilai signifikan. Apabila nilai signifikan tabel ANOVA $<0,05$ maka dapat disimpulkan bahwa hubungan bersifat linier. Uji linier dalam penelitian ini juga menggunakan spss 17.0 menghasilkan 
Tabel 6: Uji Linieritas

\begin{tabular}{|c|c|c|c|c|c|c|}
\hline \multicolumn{7}{|c|}{ ANOVA $^{\text {a }}$} \\
\hline \multicolumn{2}{|r|}{ Model } & Sum of Squares & Df & $\begin{array}{l}\text { Mean } \\
\text { Square }\end{array}$ & $\mathbf{F}$ & Sig. \\
\hline \multirow[t]{3}{*}{1} & Regression & 63676.574 & 2 & 31838.287 & 55.744 & $.000^{\mathrm{b}}$ \\
\hline & Residual & 97666.558 & 171 & 571.149 & & \\
\hline & Total & 161343.132 & 173 & & & \\
\hline \multicolumn{7}{|c|}{ a. Dependent Variabel: Karakter Siswa } \\
\hline
\end{tabular}

Berdasarkan tabel tersebut dapat dilihat bahwa nilai signifikan tabel ANOVA sebesar 0,000. Artinya nilai signifikan kurang dari $0,05(0,000<0,05)$ yang berarti bahwa hubungan bersifat linier. Hal ini menunjukan bahwa kegiatan intrakulikuler dan ekstrakulikuler berpola linier terhadap karakter siswa.

\section{Analisis Regresi Berganda}

Pengaruh kegiatan intrakulikuler (X1) dan ekstrakulikuler (X2) terhadap karakter siswa (Y) dapat dilihat dengan menggunakan analisis regresi linier berganda dengan persamaan sebagai berikut: $\mathrm{Y}=\mathrm{B}_{0}+\mathrm{B}_{1} \mathrm{X}_{1}$ $+\mathrm{B}_{2} \mathrm{X}_{2}+\mathrm{e}$, dimana : $\mathrm{Y}=$ karakter siswa, $\mathrm{B} 0$ = Konstanta ; B1, B2 = Koefisien Regresi intrakulikuler (X1) dan ekstrakulikuler (X2) dan $\mathrm{e}=$ Error. Hasil pengolahan analisis regresi berganda dengan menggunakan software SPSS diperoleh persamaan regresi linier berganda sebagi berikut: $\mathrm{Y}=$ $128.665+0.871 \mathrm{X}_{1}+0.949 \mathrm{X}_{2}+\mathrm{e}$.

Dari persamaan regresi linier berganda di atas diperoleh nilai konstanta sebesar 128.665. Artinya, jika variabel karakter siswa (Y) tidak dipengaruhi oleh kedua variabel bebasnya atau intrakurikuler (X1) dan ekstrakurikuler (X2) bernilai nol, maka besarnya rata-rata karakter siswa akan bernilai 128.665 .

Nilai koefisien regresi pada variabelvariabel bebasnya menggambarkan apabila diperkirakan variabel bebasnya naik sebesar satu unit dan nilai variabel bebas lainnya diperkirakan konstanta atau sama dengan nol, maka nilai variabel terikat diperkirakan bisa naik atau bisa turun sesuai dengan tanda koefisien regresi variabel bebasnya.

Koefisien regresi untuk variabel bebas X1 (intrakulikuler) bernilai positif, menunjukkan adanya hubungan yang searah antara intrakulikuler (X1) dengan karakter siswa (Y). Koefisien regresi variabel $\mathrm{X} 1$ sebesar 0.871 mengandung arti untuk setiap pertambahan intrakulikuler (X1) sebesar satu satuan akan menyebabkan meningkatnya karakter siswa(Y) sebesar 0.871. Koefisien regresi untuk variabel bebas X2 (ekstrakulikuler) bernilai positif, menunjukkan adanya hubungan yang searah antara ekstrakulikuler (X2) dengan karakter siswa (Y). Koefisien regresi variabel $\mathrm{X} 2$ sebesar 0.949 mengandung arti untuk setiap pertambahan ekstrakulikuler (X2) sebesar satu satuan akan menyebabkan meningkatnya karakter siswa $(\mathrm{Y})$ sebesar 0.949 .

\section{Analisis Korelasi}

Analisis korelasi digunakan untuk mengetahui hubungan kegiatan intrakurikuler dan ekstrakurikuler dengan karakter siswa. Melalui analisis korelasi ini akan dicari pengaruh variabel bebas terhadap variabel terikat. 
Tabel 7:

Pedoman Interpretasi Koefisien Korelasi ${ }^{5}$

\begin{tabular}{|c|l|l|}
\hline No & \multicolumn{1}{|c|}{ Interval Koefisien } & \multicolumn{1}{|c|}{ Tingkat hubungan } \\
\hline 1 & $0,000-0,199$ & Sangat Lemah \\
\hline 2 & $0,200-0,399$ & Lemah \\
\hline 3 & $0,400-0,5099$ & Cukup Kuat \\
\hline 4 & $0,600-0,799$ & Kuat \\
\hline 5 & $0,800-1,000$ & Sangat Kuat \\
\hline
\end{tabular}

Analisis dengan menggunakan software SPSS diperoleh hasil analisis korelasi antara variabel bebas (intrakurikuler dan ekstrakurikuler) dengan variabel terikat (karakter siswa) sebagai berikut:

Tabel 8:

Koefisien Korelasi

\begin{tabular}{|l|l|l|l|l|l|}
\hline \multicolumn{4}{|l|}{ Model Summary } \\
\hline Model & $\mathbf{R}$ & R Square & $\begin{array}{c}\text { Adjusted } \\
\text { R Square }\end{array}$ & $\begin{array}{c}\text { Std. Error } \\
\text { of the } \\
\text { Estimate }\end{array}$ & $\begin{array}{c}\text { Durbin- } \\
\text { Watson }\end{array}$ \\
\hline 1 & $.628^{\mathrm{a}}$ & .395 & .388 & 23.899 & 1.644 \\
\hline \multicolumn{5}{|l}{} \\
\hline
\end{tabular}

Pada tabel terlihat nilai R-squared dan adjusted R-square, item-item tersebut merupakan indikator seberapa besar variabel-variabel bebas mampu menjelaskan perubahan yang terjadi pada variabel terikat. Jika Regresi Linier Sederhana, maka yang dibaca adalah R-squared. Jika Regresi Linier Berganda, maka yang dibaca adalah Adjusted R-Squared. Karena nilai R-square terpengaruh oleh banyaknya jumlah variabel bebas. Semakin besar jumlah variabel bebas, maka nilai R-square akan

${ }^{5}$ Sugiyono. 2010. Metode Penelitian Pendidikan (Pendekatan Kuatintatif, Kualitatif dan R\&D), Bandung: Alfabeta, 2010, h. 183. semakin besar sehingga untuk mendapatkan nilai sebenarnya, maka dibuatlah suatu faktor koreksi. Adanya faktor koreksi akan meminimalisir pengaruh penambahan variabel sehingga dapat dilihat angka murninya. Berdasarkan tabel diperoleh nilai $38 \%$ kontribusi yang diberikan oleh variabel intrakulikuler dan ekstrakulikuler terhadap perubahan yang terjadi pada karakter siswa.

\section{Pengujian Hipotesis}

Selanjutnya untuk menguji apakah pengaruh kegiatan intrakurikuler dan ekstrakurikuler terhadap karakter siswa signifikan baik secara bersamasama (simultan) maupun secara parsial (individual), dilakukan uji signifikansi. Pengujian dimulai dari pengujian simultan, dan apabila hasil pengujian simultan signifikan dilanjutkan dengan uji parsial

Untuk mengetahui signifikan pengaruh variabel-variabel bebas secara bersamasama simultan atas suatu variabel terikat digunakan uji F.

Berdasarkan output tersebut dapat diketahui bahwa nilai F-hitung sebesar 55.744. Adapun nilai F-tabel pada tingkat signifikansi $5 \%$ dan degree of freedom (df) sebesar $\mathrm{k}=2$ dan derajat bebas penyebut (df2) sebesar $\mathrm{n}-\mathrm{k}-1(174-2-1=171)$ adalah sebesar 19,49. Jika kedua nilai ini dibandingkan maka nilai f hitung lebih besar dari F-tabel $(55.744>19,49)$, sehingga Ho ditolak. Dengan demikian dapat disimpulkan bahwa secara simultan variabel bebas (kegiatan intrakurikuler dan ekstrakurikuler) memiliki pengaruh yang sangat signifikan terhadap variabel terikat (Karakter Siswa). 


\section{Pengujian Hipotesis Secara Parsial}

Untuk mengetahui variabel yang berpengaruh signifikan secara parsial dilakukan pengujiankoefisien regresidengan menggunakan statistik Uji t. Penentuan hasil pengujian (penerimaan/ penolakan Ho) dapat dilakukan dengan membandingkan t-hitung dengan t-tabel atau dilihat dari nilai signifikansinya. Hasil pengujian hipotesis secara parsial mendapatkan output dapat dilihat dari nilai t-tabel yang diperoleh setiap variabel. Untuk membuat kesimpulan menerima atau menolak Ho, terlebih dahulu harus ditentukan nilai-nilai t-tabel yang akan digunakan. Nilai ini bergantung pada besarnya degree of freedom ( $\mathrm{df}$ ) dan tingkat signifikansi yang digunakan. Hasil pengujian pengaruh setiap kegiatan intrakurikuler dan ekstrakurikuler terhadap Karakter Siswa di SMPN 09 Lampung adalah sebagi berikut: Pertama, Pengaruh Kegiatan Intrakurikuler terhadap Karakter Siswa, bahwa berdasarkan output diketahui nilai t-hitung sebesar 4,671. Jika dibandingkan dengan nilai t-tabel sebesar 1,645 maka t-hitung yang diperoleh jauh lebih besar dari nilai t-tabel, sehingga Ho ditolak. Dengan demikian dapat disimpulkan bahwa kegiatan intrakurikuler berpengaruh secara signifikan terhadap karakter siswa. Kedua, Pengaruh Kegiatan Ekstrakurikuler terhadap Karakter Siswa, bahwa berdasarkan output diketahui nilai t-hitung sebesar 5,712. Jika dibandingkan dengan nilai t-tabel sebesar 1,645 maka t-hitung yang diperoleh jauh lebih besar dari nilai t-tabel,sehingga Ho ditolak. Dengan demikian dapat disimpulkan bahwa kegiatan ekstrakurikuler berpengaruh secara signifikan terhadap karakter siswa.

\section{Koefisien Determinasi}

Koefisien determinasi pada intinya mengukur seberapa jauh kemampuan model dalam menerangkan variasi variabel. Koefisien determinasi ini digunakan karena dapat menjelaskan kebaikan dari model regresi dalam variabel dependen. Semakin tinggi nilai koefisien determinasi maka akan semakin baik pula kemampuan variabel bebas dalam menjelaskan variabel dependen. Nilai koefisien determinasi adalah antara nol dan satu. Nilai $\mathrm{R}^{2}$ yang kecil berarti kemampuan variabel-variabel bebas dalam menjelaskan variasi variabel terikat amat terbatas. Nilai yang mendekati satu berarti variabel-variabel bebas memberikan hampir semua informasi yang dibutuhkan untuk memprediksikan variasi variabel terikat. Dengan menggunakan SPSS diperoleh koefisien determinasi sebagai berikut:

Tabel 9:

Koefisien Determinasi

\begin{tabular}{|l|c|l|l|l|l|}
\hline \multicolumn{4}{|l|}{ Model Summary } \\
\hline Model & R & R Square & $\begin{array}{c}\text { Adjusted } \\
\text { R Square }\end{array}$ & $\begin{array}{c}\text { Std.Errorof } \\
\text { the Estimate }\end{array}$ & $\begin{array}{c}\text { Durbin- } \\
\text { Watson }\end{array}$ \\
\hline 1 & $.628^{\mathrm{a}}$ & .395 & .388 & 23.899 & 1.644 \\
\hline \multicolumn{5}{|l}{} \\
a. Predictors: (Constant), Ekstrakurikuler, Intrakurikuler \\
\hline
\end{tabular}

Dari hasil output SPSS tersebut dapat dilihat bahwa nilai koefisien determinasi atau Adjusted R Square sebesar 0,388 atau $38,8 \%$. Hal ini menunjukkan bahwa variabel yang diteliti (kegiatan intrakurikuler dan ekstrakurikuler) memberikan kontribusi dalam mempengaruhi perubahan terhadap karakter siswa sebesar 38,8\%, sedangkan sisanya dipengaruhi variabel yang tidak diteliti. 


\section{PENUTUP}

Model pengembangan kegiatan intrakurikuler berbasis Pendidikan Agama Islam di SMA Negeri 09 Bandar Lampung ada pengaruh positif dan signifikan terhadap pembentukan karakter siswa. Berdasarkan analisis regresi berganda, setiap penambahan kegiatan intrakurikler sebesar satu satuan akan menyebabkan meningkatnya karakter siswa sebesar 0,871. Begitu juga model pengembangan kegiatan ekstrakurikuler berbasis Pendidikan Agama Islam ada pengaruh positif dan signifikan terhadap pembentukan karakter siswa, karena setiap penambahan sebesar satu satuan kegiatan ekstrakurikuler akan menyebabkan meningkatnya karakter siswa sebesar 0,949.

Hal ini disebabkan oleh guru yang mampu mengembangkan dirinya sejalan dengan norma-norma agama dan mampu mengamalkan dalam perkembangan ilmu pengetahuan, teknologi dan budaya, mampu membuat peserta didik berinteraksi dengan lingkungan sosial budaya dan alam sekitar. Guru mampu mengembangkan potensi dan bakat siswa, sehingga siswa mampu berkreatifitas tinggi dan penuh karya, disamping memiliki sikap disiplin, jujur, percaya diri dan bertanggung jawab dalam melaksanakan tugas, peduli sosial dan berakhlak islami. Kontribusi kegiatan intrakurikuler dan ekstrakurikuler berbasis Pendidikan Agama Islam terhadap karakter siswa sebesar $38,8 \%$. Sedangkan sisanya dipengaruhi oleh faktor keluarga, sosial budaya dan variabel lain yang tidak diteliti.

\section{UCAPAN TERIMA KASIH}

Penulis mengucapkan terima kasih kepada Kepala Puslitbang Pendidikan Agama dan Keagamaan Badan Litbang dan Diklat Kementerian Agama atas arahan dan bimbingannya. Kepada Tim Pelatihan dari Universitas Indonesia (UI) yang telah memberi bimbingan kepada penulis untuk pengolahan data penelitian kuantitatif. Kepada kepala sekolah dan para guru agama di SMA Negeri 09 Bandar Lampung yang telah bersedia memberikan data dan informasi. Semoga tulisan ini memberikan wawasan dalam pendidikan agama di Indonesia.

\section{DAFTAR PUSTAKA}

Arikunto, Suharsimi (2002): Prosedur penelitian Suatu Pendekatan Praktek, Rineka Cipta, Jakarta.

Departemen Agama RI, Direktorat Jenderal Kelembagaan Agama Islam (2005): Panduan Kegiatan Ekstrakurikuler Pendidikan Agama Islam, Jakarta

Departemen Pendidikan Nasional, Direktorat Jenderal Pendidikan Dasar dan Menengah. Undang-undang Republik Indonesia No.20 Tahun 2003 tentang Sistem Pendidikan nasional (Lembaran Negara Republik Indonesia tahun 2003 Nomor 78 dan tambahan lembaran Negara Republik Indonesia Nomor 4301)

John W Santrock, Adolesence (2003): Perkembangan Remaja, Ed. VI, Jakarta, Erlangga.

Kementerian Pendidikan Nasional (2011): Pedoman Pelaksanaan Pendidikan karakter, Jakarta, Pusat Kurikulum dan Perbukuan. 
Megawangi, Ratna(2009):Pendidikan Karakter, Solusi Tepat untuk Membangun bangsa. Jakarta, Indonesia Heritage Foundation.

Peraturan Pemerintah Nomor 55 Tahun 2007 tentang Pendidikan Agama dan Pendidikan Keagamaan

Pusat Kurikulum (2009): Pengembangan dan Pendidikan Budaya dan Karakter Bangsa, Pedoman Sekolah.

Pusat Kurikulum (2009): Pengembangan dan Pendidikan Budaya dan Karakter Bangsa, Pedoman Sekolah.

Qowaid dkk. (2014): Laporan Hasil Penelitian Penyelenggaraan Pendidikan Karakter melalui Pendidikan Agama, Puslitbang Pendidikan Agama dan Keagamaan.
Riduwan (2002): Skala Pengukuran Variabelvariabel Penelitian, Penerbit Alfa Beta, Bandung.

Sugiyono (2010: Metode penelitian pendidikan (Pendekatan kuatintatif, kualitatif dan $R \& D)$, Bandung, Alfabeta

Suryosubroto (2002): Proses Belajar Mengajar di Sekolah, PT Rineka Cipta, Jakarta

Syarbini, Amirullah (2012): Buku Pintar Pendidikan Karakter: Panduan Lengkap Mendidik Karakter Anak di Sekolah, Madrasah dan Rumah, Jakarta, Prima Pustaka. 